Jurnal Pemikiran Masyarakat Ilmiah Berwawasan Agribisnis. 2017. 3(1): 53-63

\title{
PERSEPSI PETANI TERHADAP PENGGUNAAN MESIN TETAS PADA PEMBIBITAN TERNAK AYAM BURAS (Kasus di Desa Utama Kecamatan Cijeungjing Kabupaten Ciamis)
}

\author{
SUDRAJAT \\ Fakultas Pertanian Universitas Galuh Ciamis \\ Email: sudradjat@unigal.ac.id
}

\begin{abstract}
Abstrak
Penelitian ini bertujuan untuk mengetahui persepsi petani terhadap penggunaan mesin tetas pada pembibitan ternak ayam buras. Data yang digunakan dalam penelitian ini terdiri atas data primer dan data sekunder. Data primer diperoleh melalui wawancara langsung dengan petani ternak ayam buras menggunakan kuesioner yang telah dipersiapkan sebelumnya, sedangkan data sekunder diperoleh dari dinas/instansi yang terkait dengan penelitian. Penentuan responden dilakukan secara sensus terhadap seluruh anggota Kelompok Tani Makmur, yaitu sebanyak 43 orang yang menjadi peserta pelatihan aplikasi teknologi reproduksi ternak ayam buras yang diselenggarakan LPPM Universitas Galuh di Desa Utama Kecamatan Cijeungjing Kabupaten Ciamis. Persepsi petani terhadap penggunaan mesin tetas pada pembibitan ternak ayam buras dilihat dari indikator sifat inovasi yaitu relative advantage, compatibility, complexity, triability, dan observability. Analisis data dilakukan dengan menggunakan analisis rataan skor. Hasil penelitian menunjukkan bahwa persepsi petani terhadap penggunaan mesin tetas pada pembibitan ternak ayam buras termasuk kedalam kategori cukup baik. Dengan demikian teknologi mesin tetas tersebut dapat diterima dan berpeluang untuk diadopsi oleh para petani ternak ayam buras.
\end{abstract}

Kata kunci : persepsi, mesin tetas, ayam buras

\begin{abstract}
This study aims to determine the perception of farmers on the use of the incubator in domestic poultry breeding. The data used in this study consisted of primary data and secondary data. The primary data obtained through interviews with domestic poultry livestock farmers use pre-prepared questionnaires, while secondary data obtained from the offices/institutions associated with the research. Respondent conducted a census of all members of the Prosperous Farmers Group, as many as 43 people who participated in the livestock reproductive technology application training organized domestic poultry in the village LPPM Galuh University in Utama Village, District of Cijeungjing District, Ciamis Regency. Perception of farmers on the use of the incubator in domestic poultry breeding nature of the innovation seen from the indicators are relative advantage, compatibility, complexity, triability, and observability. Data analysis was performed using analysis of the average score. The results showed that the perception of farmers on the use of the incubator in domestic poultry breeding included into the category quite well. Thus the technology incubator is unacceptable and likely to be adopted by livestock farmers freerange chicken.
\end{abstract}

Keywords: Perception, Incubator, domestic poultry 
Persepsi Petani Terhadap Penggunaan Mesin Tetas Pada Pembibitan Ternak Ayam Buras (Kasus di Desa Utama Kecamatan Cijeungjing Kabupaten Ciamis)

SUDRAJAT

\section{PENDAHULUAN}

Kebutuhan masyarakat akan konsumsi daging dan telur terus mengalami peningkatan seiring dengan pertumbuhan penduduk yang terus meningkat dari tahun ke tahun. Selain itu, meningkatnya permintaan masyarakat terhadap daging dan telur, juga didorong oleh meningkatnya kesadaran masyarakat akan kebutuhan makanan bergizi.

Salah satu upaya yang dapat dilakukan untuk memenuhi permintaan daging dan telur yaitu dengan pengembangan intensifikasi ayam buras (usaha agribisnis ayam buras), karena ayam buras tersebar luas di setiap pedesaan dan masyarakat sudah terbiasa memeliharanya, selain relatif mudah dan tidak membutuhkan modal besar, juga dapat beradaptasi dengan lingkungan dan mampu memanfaatkan limbah, serta tidak mengganggu lahan usahatani lainnya (Pramudyati, 2009). Namun demikian petani yang mengusahakan ayam buras secara komersial masih terbatas jumlahnya. Hal tersebut disebabkan ketersediaan bibit siap telur untuk usaha peternakan ayam buras petelur dan DOC untuk usaha peternakan ayam buras pedaging relatif masih sulit didapat.

Terobosan yang diperlukan untuk mengatasi masalah tersebut diantaranya melalui pemanfaatan teknologi reproduksi, baik melalui pendekatan kuantitatif (peningkatan populasi) maupun pendekatan kualitatif atau produktivitas per unit ternak (Sumaryadi, dkk, 2010). Sejalan dengan hal tersebut, Hafez (1993) menyatakan bahwa penerapan teknologi reproduksi sangat penting peranannya dalam meningkatkan produksi dan produktivitas ternak.

Aplikasi teknologi reproduksi yang bisa diterapkan pada usahatani ternak ayam buras yaitu dengan memperpendek siklus reproduksi melalui penggunaan mesin penetas telur. Pramudyati (2009) menyatakan, bahwa mesin penetas telur adalah alat yang berfungsi untuk menggantikan induk yang sedang mengerami, sehingga alat tersebut diciptakan sesuai kondisi induk yang sedang mengerami telur.

Teknologi penetasan telur menggunakan mesin tetas telah didifusikan ke kelompok tani ternak ayam buras yang tersebar di wilayah Kabupaten Ciamis, termasuk di Desa Utama Kecamatan Cijeungjing, namun demikian belum diketahui bagaimana persepsi petani terhadap teknologi tersebut.

Untuk mengetahui persepsi petani terhadap penggunaan mesin tetas pada pembibitan ternak ayam buras dapat diukur 
Jurnal Pemikiran Masyarakat Ilmiah Berwawasan Agribisnis. 2017. 3(1): 53-63

berdasarkan karakteristik teknologi atau inovasi tersebut. Ada lima ciri inovasi yang dapat digunakan sebagai indikator dalam mengukur persepsi antara lain : 1) Keuntungan relatif (relative advantages), 2) Kesesuaian (compatibility), 3) Kerumitan (complexity), 4) Kemungkinan untuk dicoba (triability), dan 5) Mudah diamati (observability).

Berdasarkan uraian tersebut, maka penelitian ini bertujuan untuk mengetahui persepsi petani terhadap penggunaan mesin tetas pada pembibitan ternak ayam buras di Desa Utama Kecamatan Cijeungjing Kabupaten Ciamis.

\section{TINJAUAN PUSTAKA}

\section{Persepsi}

Persepsi adalah kemampuan untuk melihat, mendengar, atau mengetahui sesuatu melalui indera (Oxford Dictionaries, 2013). Persepsi adalah proses bagaimana stimuli-stimuli itu diseleksi, diorganisasikan dan diinterpretasikan (Solomon dalam Sutisna, 1999). Menurut Mulyana (2001), persepsi merupakan proses yang memungkinkan suatu organisme menerima dan menganalisis informasi.

Persepsi menyangkut kognisi yang mencakup kegiatan mental (otak), penafsiran objek, tanda, orang serta pengalaman yang bersangkutan (Mulyana, 2004). Ada dua faktor yang mempengaruhi proses pembentukan persepsi yaitu faktor struktural dan faktor fungsional. Faktor struktural berasal semata-mata dari sifat rangsangan (stimuli) fisik dan efek-efek syaraf yang ditimbulkannya pada system syaraf individu. Itu berarti secara struktural persepsi ditentukan oleh jenis dan bentuk rangsangan yang diterima. Sedangkan faktor fungsional berasal dari kebutuhan, pengalaman masa lalu dan hal-hal lain yang termasuk ke dalam faktor pribadi, jadi yang menentukan persepsi secara fungsional ialah karakteristik orang yang memberi respon terhadap rangsangan tersebut (Rakhmat, 2004).

Menurut Walgito (2004) untuk mengadakan persepsi ada beberapa faktor yang berperan yang merupakan syarat agar terjadi persepsi yaitu :

1) Objek yang dipersepsi

Objek menimbulkan stimulus yang mengenai alat indera atau reseptor. Stimulus dapat dating dari luar individu yang mempersepsi, tetapi juga dapat datang dari dalam individu yang bersangkutan yang langsung mengenai syaraf penerima yang bkerja sebagai reseptor.

2) Alat indera, syaraf dan pusat susunan syaraf 
Persepsi Petani Terhadap Penggunaan Mesin Tetas Pada Pembibitan Ternak Ayam Buras (Kasus di Desa Utama Kecamatan Cijeungjing Kabupaten Ciamis)

\section{SUDRAJAT}

Alat indera atau reseptor merupakan alat untuk menerima stimulus. Disamping itu juga harus ada syaraf sensoris sebagai alat untuk meneruskan stimulus yang diterima dari reseptor ke pusat susunan syaraf, yaitu otak sebagai pusat kesadaran. Sebagai alat untuk mengadakan respon diperlukan syaraf motoris.

3) Perhatian

Untuk menyadari alat untuk mengadakan persepsi diperlukan adanya perhatian, yaitu merupakan langkah pertama sebagai suatu persiapan dalam rangka mengadakan persepsi. Perhatian merupakan pemusatan atau konsenstrasi dari seluruh aktivitas yang ditujukan kepada sesuatu atau sekumpulan objek.

Krech dan Crutfield (1977) dalam Rakhmat (2003) merumuskan empat dalil tentang persepsi sebagai berikut :

1) Persepsi bersifat selektif secara fungsional, dalil ini berarti bahwa objek-objek yang mendapat tekanan dalam persepsi kita biasanya objekobjek yang memenuhi tujuan individu yang melakukan persepsi. Mereka memberikan contoh pengaruh kebutuhan, kesiapan mental, suasana emosional, dan latar belakang budaya terhadap persepsi.

2) Medan perseptual dan kognitif selalu diorganisasikan dan diberi arti.

Seseorang mengorganisasikan stimuli dengan melihat konteksnya, walaupun stimuli yang diterima itu tidak lengkap, seseorang akan mengisinya dengan interprestasi yang konsisten dengan rangkaian stimuli yang dipersepsikan.

3) Sifat-sifat perseptual dan kognitif dari substruktual ditentukan pada umumnya oleh sifat-sifat struktur secara keseluruhan. Jika individu dianggap sebagai anggota kelompok, semua sifat individu yang berkaitan dengan sifat kelompok akan dipengaruhi oleh keanggotaan kelompoknya, dengan efek yang berupa asimilasi atau kontras.

4) Objek atau peristiwa yang berdekatan dalam ruang dan waktu atau menyerupai satu sama lain, cenderung ditanggapi sebagai bagian dari struktur yang sama.

$$
\text { Adesina and Zinnah }
$$
menyatakan bahwa persepsi adopter terhadap inovasi teknologi mempengaruhi proses adopsi inovasi teknologi yang diusulkan. Jika persepsi 
Jurnal Pemikiran Masyarakat Ilmiah Berwawasan Agribisnis. 2017. 3(1): 53-63

adopter positif, maka inovasi teknologi tersebut cenderung lebih cepat diadopsi.

Ada lima ciri inovasi yang dapat digunakan sebagai indikator dalam mengukur persepsi antara lain (Wahyuni, 2002) :

1) Keuntungan relatif (relative advantages), adalah merupakan tingkatan di mana suatu ide baru dianggap suatu yang lebih baik daripada ide-ide yang ada sebelumnya dan secara ekonomis menguntungkan.

2) Kesesuaian (compatibility), adalah sejauh mana suatu inovasi dianggap konsisten dengan nilai-nilai yang ada , pengalaman masa lalu dan kebutuhan adopter (penerima). Oleh karena itu, inovasi yang tidak kompatibel dengan ciri-ciri sistem sosial yang menonjol akan tidak diadopsi secepat ide yang kompatibel.

3) Kerumitan (complexity), adalah suatu tingkat di mana suatu inovasi dianggap relatif sulit untuk dimengerti dan digunakan. Kesulitan untuk dimengerti dan digunakan, akan merupakan hambatan bagi proses kecepatan adopsi inovasi.

4) Kemungkinan untuk dicoba (triability), adalah suatu tingkat di mana suatu inovasi dapat dicoba dalam skala kecil. Ide baru yang dapat dicoba dalam skala yang lebih kecil biasanya diadopsi lebih cepat daripada inovasi yang tidak dapat dicoba lebih dulu.
5) Mudah diamati (observability), adalah suatu tingkat di mana hasil-hasil suatu inovasi dapat dengan mudah dilihat orang lain, sehingga akan mempercepat proses adopsinya. Jadi calon-calon pengadopsi lainnya tidak perlu lagi menjalani tahap-tahap percobaan, melainkan dapat terus ke tahap adopsi.

\section{Mesin Penetas}

Mesin tetas merupakan sebuah peti atau lemari dengan konstruksi yang dibuat sedemikian rupa sehingga panas didalam tidak terbuang. Suhu di dalam peti/lemari/box dapat diatur sesuai ukuran derajat panas yang dibutuhkan selama periode penetasan. Prinsip kerja penetasan telur dengan mesin tetas ini sama dengan induk unggas (Farry, 2011). Prinsip penetasan telur dengan menggunakan mesin tetas (incubator) adalah sama dengan penetasan menggunakan induk, hanya berbeda pada jumlah telur yang ditetaskan. Semakin besar incubator yang digunakan, semakin besar pula jumlah telur yang dapat ditetaskan (Sumantri, 2000).

Nafiu, dkk. (2014) menyatakan, bahwa mesin tetas berfungsi sebagai pengganti induk dalam penetasan telur untuk menghasilkan anak ayam. Keunggulan penerapan teknologi mesin tetas adalah menghilangkan periode mengeram pada induk, sehingga induk 
Persepsi Petani Terhadap Penggunaan Mesin Tetas Pada Pembibitan Ternak Ayam Buras (Kasus di Desa Utama Kecamatan Cijeungjing Kabupaten Ciamis)

SUDRAJAT

lebih produktif dan mampu menghasilkan telur lebih banyak selama hidupnya. Selain itu anak ayam dapat diproduksi dalam jumlah yang banyak pada waktu yang bersamaan dan kapasitas penetasan dapat diperbanyak sesuai dengan jumlah telur tetas yang siap ditetaskan.

Pada prinsipnya penetasan telur dengan mesin tetas adalah menyediakan lingkungan yang sesuai untuk perkembangan embrio (calon anak), yakni meniru sifat-sifat alamiah induk ayam atau itik yang mengerami telur, yaitu menyesuaikan suhu, kelembaban, dan membalik telur yang dierami (Subiharta dan Yuwana, 2012). Penetasan buatan mampu menetaskan jumlah telur dalam jumlah ratusan bahkan ribuan butir, tergantung kapasitas tampung mesin tetas (Kartasudjana, 2001).

\section{METODE PENELITIAN}

Penelitian ini dilaksanakan di Desa Utama Kecamatan Cijeungjing Kabupaten Ciamis dengan menggunakan metode survai. Penarikan sampel dilakukan secara sensus terhadap seluruh anggota Kelompok Tani Makmur, yaitu sebanyak 43 orang yang mengikuti pelatihan aplikasi teknologi reproduksi ternak ayam buras yang diselenggarakan LPPM Universitas Galuh.
Data yang digunakan dalam penelitian ini terdiri atas data primer dan data sekunder. Data primer diperoleh melalui wawancara langsung dengan petani ternak ayam buras menggunakan kuesioner yang telah dipersiapkan sebelumnya, sedangkan data sekunder diperoleh dari dinas/instansi yang terkait dengan penelitian.

Definisi operasional dari variabelvariabel yang diteliti adalah sebagai berikut :

- Persepsi petani terhadap penggunaan mesi tetas adalah penilaian dan pernyataan responden tentang digunakannya mesin tetas pada pembibitan ayam buras, yang meliputi : relative advantage, compatibility, complexity, triability, dan observability.

1) Relative advantage adalah tingkatan dimana penggunaan mesin tetas pada pembibitan ayam buras dianggap lebih baik dibandingkan sistem pengelolaan reproduksi sebelumnya dan secara ekonomis menguntungkan, penialain dengan sistem skoring.

2) Compatibility adalah sejauh mana penggunaan mesin tetas pada pembibitan ayam buras dianggap konsisten dengan nilai-nilai yang ada, pengalaman masa lalu, dan kebutuhan 
Jurnal Pemikiran Masyarakat Ilmiah Berwawasan Agribisnis. 2017. 3(1): 53-63

petani, penilaian dengan sistem skoring.

3) Complexity adalah tingkat di mana penggunaan mesin tetas pada pembibitan ayam buras dianggap mudah diterapkan, penilaian dengan sistem skoring.

4) Triability adalah tingkat dimana penggunaan mesin tetas pada pembibitan ayam buras dapat dicoba dengan skala kecil sehingga akan memperkecil resiko bagi petani, penilaian dengan sistem skoring.

5) Observability, adalah tingkat dimana penggunaan mesin tetas pada pembibitan ayam buras hasilnya mudah dilihat, penilaian dengan sistem skoring.

Data yang dikumpulkan dinalisis menggunakan analisis rataan skor, kemudian total nilai yang didapat dikelompokkan berdasarkan rentang skala (Vredenbregt, 1987) sebagaimana dapat dilihat pada Tabel 1 .

Tabel 1. Kategori Persepsi Berdasarkan Rentang Skala

\begin{tabular}{ccc}
\hline No & $\begin{array}{c}\text { Rentang Skala } \\
(\%)\end{array}$ & Kategori \\
\hline 1. & $0,00-33,33$ & Tidak Baik \\
2. & $33,34-66,67$ & Cukup Baik \\
3. & $66,68-100,00$ & Baik \\
\hline
\end{tabular}

\section{HASIL DAN PEMBAHASAN}

\section{Karakteristik Petani}

Karakteristik petani yang diamati dalam penelitian ini meliputi : umur, pendidikan, tanggungan keluarga, pengalaman berusahatani, dan skala usaha.

\section{Umur}

Umur para petani ternak ayam buras di Kelompok Tani Makmur berkisar antara 23 sampai dengan 59 tahun. Hal tersebut menunjukkan bahwa para petani berada pada usia produktif. Menurut Wirosuhardjo (2004) bahwa kategori usia produktif yaitu antara 15 sampai dengan 64 tahun.

\section{Pendidikan}

Sebagian besar petani ternak ayam buras di Kelompok Tani Makmur tingkat pendidikannya relatif cukup baik, karena di atas rata-rata tingkat pendidikan para petani di Indonesia pada umumnya.

\section{Tanggungan Keluarga}

Jumlah tanggungan keluarga para petani ternak ayam buras di Kelompok Tani Makmur sebagian besar yaitu sebanyak 38 orang $(88,37 \%)$ mempunyai tanggungan keluarga kurang dari 1-3 orang, sedangkan sisanya yaitu sebanyak 5 orang $(11,63 \%)$ mempunyai tanggungan keluarga sebanyak 4 orang. 
Persepsi Petani Terhadap Penggunaan Mesin Tetas Pada Pembibitan Ternak Ayam Buras (Kasus di Desa Utama Kecamatan Cijeungjing Kabupaten Ciamis)

SUDRAJAT

\section{Pengalaman Berusahatani}

Sebagian besar petani ternak ayam buras di Kelompok Tani Makmur yaitu sebanyak 32 orang atau 74,42 persen pengalaman berusahataninya cukup lama, karena sudah lebih dari 10 tahun.

Pengalaman berusahatani akan mempengaruhi seseorang untuk melakukan suatu kegiatan usaha ke arah yang lebih efisien, artinya semakin lama pengalaman yang dimilikinya akan membuat seseorang lebih terampil dan efisien dalam menjalankan usahanya.

Demikian halnya dengan para petani di Kelompok Tani Makmur, mereka memiliki keterampilan yang semakin baik dalam berusahatani, sehingga usaha yang dijalankannyapun semakin efisien. Para petani di Kelompok Tani Makmur juga semakin memiliki kemampuan yang baik dalam mengatasi berbagai permasalahan yang dihadapinya. Oleh karena itu, persepsinya terhadap penggunaan mesin tetas cukup baik, setelah mengetahui teknologi tersebut dapat meningkatkan efisiensi pada usahatani ternak ayam buras yang dijalankannya.

\section{Skala Usaha}

Kegiatan usahatani ternak ayam buras yang dijalankan para petani di Kelompok Tani Makmur skala usahanya tergolong ke dalam kelompok skala kecil, karena jumlah kepemilikan bibit ternak ayam buras yang diusahakannya kurang dari 50 ekor.

Namun demikian, karena usahanya diarahkan kepada pembibitan dan mereka mengusahakannya secara berkelompok, sehingga kehadiran teknologi mesin tetas sangat dibutuhkan dan memungkinkan untuk diterapkan, sehingga persepsi petani terhadap terknologi tersebut cukup baik.

\section{Persepsi Petani Terhadap Penggunaan Mesin Tetas}

Persepsi adalah pengalaman seseorang tentang obyek, peristiwa, atau hubunganhubungan yang diperoleh dengan menyimpulkan informasi dan menafsirkan pesan (Rahmat, 2004). Persepsi merupakan rangkaian tiga jenis proses yaitu : seleksi, organisasi dan interpretasi (Mulyana, 2001).

Menurut Rogers (1983), tingkat adopsi dari suatu inovasi tergantung pada persepsi adopter tentang karakteristik inovasi teknologi tersebut.

Hasil penelitian menunjukkan, bahwa persepsi petani terhadap penggunaan mesin tetas pada pembibitan ternak ayam buras, yang meliputi persepsi terhadap keuntungan relatif (relative advantage), tingkat kesesuaian (compatibility), tingkat kerumitan 
Jurnal Pemikiran Masyarakat Ilmiah Berwawasan Agribisnis. 2017. 3(1): 53-63

(complexity), tingkat kemudahan dapat dicoba (triability), dan tingkat kemudahan untuk dilihat hasilnya (observability) termasuk kedalam kategori cukup baik. Dengan demikian, teknologi mesin tetas tersebut dapat diterima dan berpeluang untuk diadopsi oleh para petani ternak ayam buras.

Penilaian tingkat persepsi petani terhadap penggunaan mesin tetas pada pembibitan ternak ayam buras di Kelompok Tani Makmur Desa Utama Kecamatan Cijeungjing Kabupaten Ciamis dapat dilihat pada Tabel 2.

Tabel 2. Penilaian Persepsi Petani Terhadap Penggunaan Mesin Tetas

\begin{tabular}{l|c|c}
\hline Persepsi Petani & $\begin{array}{c}\text { Tingkat } \\
\text { Persepsi } \\
(\%)\end{array}$ & Kategori \\
\hline Relative advantage & 60 & Cukup Baik \\
Compatibility & 66 & Cukup Baik \\
Complexity & 57 & Cukup Baik \\
Triability & 59 & Cukup Baik \\
Observability & 62 & Cukup Baik \\
\hline
\end{tabular}

Berdasarkan Tabel 2 diketahui, bahwa persepsi petani terhadap penggunaan mesin tetas dilihat dari seluruh indikator yang merupakan ciri inovasi menunjukkan persepsi yang cukup baik. Hal tersebut menunjukkan, bahwa teknologi mesin tetas dipandang petani lebih menguntungkan dibandingkan penerapan teknologi sebelumnya, baik dari segi keuntungan ekonomis maupun kelebihan teknis, sesuai dengan kebutuhan, tidak rumit (sederhana), mudah untuk dicoba dan diterapkan, serta mudah dilihat hasilnya.

Nilai persepsi petani terhadap tingkat kesesuaian (compatibility) menunjukkan nilai yang paling tinggi yaitu $66 \%$. Hal tersebut menunjukkan bahwa secara deskriptif tingkat kesesuaian teknologi merupakan faktor yang paling mempengaruhi persepsi petani terhadap penggunaan mesin tetas.

Bagi para petani yang mengusahakan pembibitan ternak ayam buras, teknologi mesin tetas sangat dibutuhkan atau sesuai dengan kebutuhan petani, karena selain dapat memperpendek siklus reproduksi dan meningkatkan produktivitas juga anak (DOC) yang dihasilkan relatif seragam, sehingga memudahkan dalam penanganan. Menurut Sudaryanto (2002), teknologi yang mampu merespon keinginan dan kebutuhan masyarakat untuk mengembangkan suatu komoditas yang spesifik lokasi, maka teknologi tersebut akan berlanjut.

\section{PENUTUP}

Persepsi petani terhadap penggunaan mesin tetas pada pembibitan ternak ayam buras termasuk kedalam kategori cukup baik, sehingga teknologi mesin tetas tersebut dapat diterima dan berpeluang 
Persepsi Petani Terhadap Penggunaan Mesin Tetas Pada Pembibitan Ternak Ayam Buras (Kasus di Desa Utama Kecamatan Cijeungjing Kabupaten Ciamis)

\section{SUDRAJAT}

untuk diadopsi oleh para petani ternak ayam buras.

Berdasarkan uraian di atas, maka dapat diajukan rekomendasi kegiatan, yaitu: pelatihan aplikasi teknologi reproduksi ternak ayam buras perlu dikembangkan lebih luas untuk mendorong persepsi petani ke arah yang lebih baik.

\section{DAFTAR PUSTAKA}

Hafez, ESE. 1993. Reproduction in Farm Animals. $6^{\text {th }}$ Edition. Lea Febiger. Philadelphia.

Jakarta. Mulyana, B. 2001. Ilmu-Ilmu Komunikasi. Edisi Revisi. Bandung : Remaja Rosdakarya.

Kartasudjana, R., 2001. Penetasan Telur. Proyek Pengembangan Sistem dan Standar Pengelolaan Smkdirektorat Pendidikan Menengah Kejuruan. Departemen Pendidikan Nasional.

Mulyana, Deddy. 2004. Ilmu Komunikasi, Suatu Pengantar. Bandung : PT Remaja Rosdakarya.

Nafiu, L.O., M. Rusdin, A.S. Aku. 2014. Daya Tetas dan Lama Menetas Telur Ayam Tolaki Pada Mesin Tetas dengan Sumber Panas yang Berbeda. Jitro I (1) : 32-44.

Oxford Dictionaries .2013. Perception. www.oxforddictionaries.com $\lfloor 23 / 1$ 2/1013]

Parry B. Paimin. 2011. Mesin Tetas. Jakarta. Swadaya.

Pramudyati, Y.S. 2009. Petunjuk Teknis Beternak Ayam Buras. GTZ Merang Reed Pilot Project Bekerjasama dengan Balai Pengkajian Teknologi Pertanian (BPTP) Sumatera Selatan. Palembang.
Rakhmat, J. 2003. Psikologi Komunikasi. Bandung: PT. Remaja Rosdakarya.

Rakhmat, J. 2004. Psikologi Komunikasi. Bandung : PT Rosdakarya Group.

Rogers, E.M. 1983. Diffution of Innovations. The Free Press, New York.

Subiharta dan Yuwana, D.M., 2012. Pengaruh penggunaan bahan tempat air dan letak telur di dalam mesin tetas yang perpemanas listrik pada penetasan itik tegal. Seminar Nasional Kedaulatan Pangan dan Energi 1-7.

Sudaryanto, dan E. Basuno. 2002. Peran Teknologi Pertanian Partisipatif dalam Meningkatkan Diversifikasi Produk Pangan Spesifik Lokasi. Monograf Analisis Kebijaksanaan:

Pendekatan Pembangunan dan Kebijaksanaan Pengembangan Agribisnis. Pusat Penelitian dan Pengembangan Sosial Ekonomi Pertanian, Bogor.

Sumantri. 2000. Teknis Penetasan Telur Semi Intensif. Temu Teknis Fungsional Non Peneliti. Bogor : Balai Penelitian Ternak.

Sumaryadi, M.Y., Saleh, D,M., Haryanto, B., Herdiansah, D., Sudradjat, dan Yasin, C.A. 2010. Kajian Aspek Reproduksi dan Estimasi Ekonomi pada Ternak Sapi yang Diinovasi Teknologi Reproduksi. Jurnal Agripet 11(1) : 1-6..

Sutisna. 1999. Perilaku Konsumen dan Komunikasi Pemasaran. Bandung : Remaja Rosdakarya.

Vredenbregt, J. 1987. Metode dan Teknik Penelitian Masyarakat. Jakarta : PT. Gramedia.

Wahyuni, S. 2002. Hubungan karakteristik dan perilaku komunikasi petani dengan persepsinya terhadap inovasi teknologi alat mesin pertanian. Tesis. Program Pascasarjana. Institut Pertanian Bogor. Bogor. 
Jurnal Pemikiran Masyarakat Ilmiah Berwawasan Agribisnis. 2017. 3(1): 53-63

Walgito, B. 2004. Pengantar Psikologi Umum. Yogyakarta: Penerbit ANDI.

Wirosuharjo. 2004. Dasar-dasar Demografi. Jakarta : Fakultas Ekonomi Universitas Indonesia. 